Nevertheless, a specific effect on the critical VLD fraction may have been overlooked. On the other hand, it was recently reported that the ethanol-induced increase in liver lipid was associated with a decrease in the level of serum high-density lipoproteins. ${ }^{16}$ These results, together with those presented in Table 1, are indicative of a nonspecific disturbance of hepatic lipoprotein secretion by ethanol.

If a causal role in the ethanol-induced accumulation of liver triglycerides is to be attributed to decreased formation or release (or both) of hepatic lipoproteins, the reduction in the level of serum VLD lipropoteins must be present prior to the rise in liver triglycerides, as in the case of carbon tetrachloride. ${ }^{8}$ Such a role may now be postulated because experiments in this laboratory and elsewhere ${ }^{3,5}$ have shown that an increase in liver triglyceride levels does not begin until 6-8 hr after administration of the standard dose of ethanol.

Acknowledgements-This work was supported by grants from The Wellcome Trust and the Sir A. E. Rowden White and Edward White Trust.

Pathology Department,

N. P. MADSEN

University of Melbourne,

Parkville, Victoria 3052,

Australia

\title{
REFERENCES
}

1. K. J. Isselbacher and N. J. Greenberger, New Engl. J. Med. 270, 402 (1964).

2. B. LOMBARDI, Lab. Invest. 15, 1 (1966).

3. E. E. Elko, W. R. Wooles and N. R. Di Luzio, Am. J. Physiol. 201, 923 (1961).

4. D. ZAKim, D. AleXANDer and M. H. Sleisenger, Clin. Res. 12, 448 (1964).

5. N. R. Di Luzio, Lab. Invest. 15, 50 (1966).

6. R. H. Schapiro, G. D. Drummey, Y. Shimtzu and K. J. Isseldachier, J. clin. Invest. 43, 1338 (1964).

7. R. M. Dajani and C. Kouyoumjian, J. Nutr. 91, 535 (1967).

8. B. Lombardi and G. Ugazto, J. Lipid Res. 6, 498 (1965).

9. G. UGAZIO and B. Lombard, Lab. Invest. 14, 711 (1965).

10. R. J. HAVEL, H. A. Eder and J. H. Bragdon, J. clin. Invest. 34, 1345 (1955).

11. O. H. Lowry, N. J. Rosebrough, A. L. Farr and R. J. Randall, J. biol. Chem. 193, 265 (1951).

12. S. P. Chiang, C. F. Gessert and O. H. Lowry, U.S. Air Force School of Aviation Medicine, Research Report 56-113 (1957).

13. M. BuRstein, Nouv. Revue fr. Hémat. 3, 139 (1963).

14. J. Folch, M. Lees and G. H. Sloane Stanley, J. biol. Chem. 226, 497 (1957).

15. A. Seakins and D. S. RobInson, Biochem. J. 92, 308 (1964).

16. S. Koga and C. Hirayama, Experientia 24, 438 (1968).

Biochemical Pharmacology, Vol. 18, pp. 262-265. Pergamon Press. 1996. Printed in Great Britain

\section{Determination of rat liver hexobarbital oxidase activity with a gaschromatographic method}

(Received 4 April 1968; accepted 30 September 1968)

IN TOXICITY experiments the determination of the so called "drug metabolizing enzymes" or "processing enzymes"1 becomes more and more of importance since it was demonstrated that many drugs and insecticides have the capacity to stimulate this type of microsomal enzymes. ${ }^{2,3}$ One of the determinations, which are frequently used for this purpose, is the hexobarbital oxidase activity of liver microsomal fraction. In most experiments the non-metabolized hexobarbital after incubation is determined according to Cooper and Brodie. ${ }^{4}$ This requires a time consuming extraction procedure after which the hexobarbital is measured by u.v, spectrophotometry. 
In the literature a number of methods are described for determination of barbiturates in blood with the aid of a gaschromatograph. ${ }^{5-7}$ In our laboratory a modification of this method was used for measurement of barbiturates in blood. To determine the sidechain oxidation of hexobarbital we have modified the method of Cooper and Brodie $^{4}$ by measuring the quantity of non-metabolised hexobarbital in the reaction mixture with this gaschromatographic method. To simplify the extraction procedure an internal standard was introduced. From preliminary experiments it appeared that methylphenobarbital could be used as such.

This method was tested by measuring the stimulation of hexobarbital metabolism by some organochlorine pesticides.

Male Wistar rats $(200-300 \mathrm{~g})$ were given one oral dose of the following pesticides: DDT*, dieldrin, lindane, dicofol, tetradifon, chlorfenson and dichlobenil in olive oil. Approximately a half oral LD50 was chosen as a dose level. Three days after administration of the pesticides the rats were killed with carbon dioxide. The liver was removed, homogenized at $4^{\circ}$ with 2 vol. of $0.2 \mathrm{M} \mathrm{Na}_{2} \mathrm{HPO}_{4}-\mathrm{KH}_{2} \mathrm{PO}_{4}$ buffer ( $\mathrm{pH} \mathrm{7.4)}$ and centrifuged at $9000 \mathrm{~g}$ for $20 \mathrm{~min}\left(4^{\circ}\right)$. Incubation was carried out in a shaking waterbath at $37^{\circ}$ for $1 \mathrm{hr}$ with 1 or $3 \mathrm{ml}$ supernatant fraction and $0.055 \mu$ mole NADP, $5 \mu$ mole glucose-6-phosphate, $10 \mu$ mole nicotinamid, $5 \mu$ mole $\mathrm{MgSO}_{4}$, and $3 \mu$ mole hexobarbital (Evipan $\mathrm{Na}$, Bayer) made to a final vol. of $5 \mathrm{ml}$ with phosphate buffer. To obtain the standard value the same mixture is used, except that liver supernatant is replaced by phosphate buffer. The reaction is stopped by adding $25 \mathrm{ml}$ of chloroform and $1 \mathrm{ml}$ of methylphenobarbital solution ( $25 \mathrm{mg}$ in $50 \mathrm{ml}$ of chloroform) to each incubation vessel. After shaking the mixture is centrifuged during $12 \mathrm{~min}$ and the aqueous phase is removed. The chloroform is evaporated till dryness. The residue is taken up in $0 \cdot 2 \mathrm{ml}$ of chloroform.

The gaschromatograph employed was the Aerograph Model 550 with hydrogen flame ionization detector and a Honeywell $1 \mathrm{mV}$ recorder. The chromatographic column $\left(3 \mathrm{ft} \times \frac{1}{8}\right.$ in. pyrex) was packed with $70 / 100$ mesh Celite AW-DMCS, coated with $3 \%$ neopentylglycolsebacate. The operation conditions were: injector temperature $230^{\circ}$, oven temperature $200^{\circ}$; flow rate of carrier gas $\left(\mathrm{N}_{2}\right)$ $30 \mathrm{ml} / \mathrm{min}$, flow rate of hydrogen $30 \mathrm{ml} / \mathrm{min}$.

The calculation was done by area measurement (height $\times$ width on half height) of the peaks from hexobarbital (hexo) and methylphenobarbital (me phe). The amount of hexobarbital in each extract was calculated according to the formula:

$\mu \mathrm{g}$ hexo $=$ area ratio hexo/me phe $\times \mu \mathrm{g}$ added me phe $\times$ a constant factor

The amount of metabolized hexobarbital i.e. the difference between the standard value, which is extracted and determined in the same manner, and the residual amount was calculated as the percentage of the standard value.

In Fig. 1 it is shown that a relationship exists between the weight ratio and the arca ratio of hexobarbital and methylphenobarbital with a constant factor of about 1 . Since all results are calculated as the percentage of the standard value, which is treated in the same manner, this factor can be neglected.

In Fig. 2 an example is given of a gaschromatographic pattern of an extract from the incubated liver supernatant mixture. In addition to the solvent peak two peaks are present which probably originate from the added cofactors. These peaks, however, do not overlap the peaks of hexobarbital and methylphenobarbital, which are separated very well.

In Table 1 the results are given of the activity of hexobarbital oxidase in control livers. The values are expressed as the percentages metabolized of the dose of hexobarbital which was added (standard value). Since some experiments have been carried out with $1 \mathrm{ml}$ and others with $3 \mathrm{ml}$ liver supernatant, both values are given.

In Table 2 the hexobarbital oxidase activity is given in liver microsomes of rats which are treated with several organochlorine pesticides. The results from this table indicate that all pesticides induce an increase in hexobarbital oxidase activity, 3 days after one oral dose.

\footnotetext{
* DDT $=p, p^{\prime} \mathrm{DDT}=1,1,1$-trichloro-2,2-bis-(4-chlorophenyl)-ethane dieldrin $=1,2,3,4,10,10^{\mathrm{a}}$-hexachloro-6,7-epoxi-1,4,4a, $5,6,7,8,8^{\mathrm{a}}$-octahydro-1 $4,5,8$-dimethano-naphtalene

lindane $=1,2,3,4,5,6$-hexachlorocyclohexane ( $\gamma$-isomer)

dicofol $=1,1$-bis-(4-chlorophenyl)-2,2,2-trichloroethanol (Kelthane)

tetradifon $=2,4,5,4^{\prime}$-tetrachlorodiphenylsulphone (Tedion)

chlorfenson $=4$-chlorophenyl-4-chlorobenzene sulphonate

dichlobenil $=2,6$-dichlorobenzonitrile (Casoron)
} 


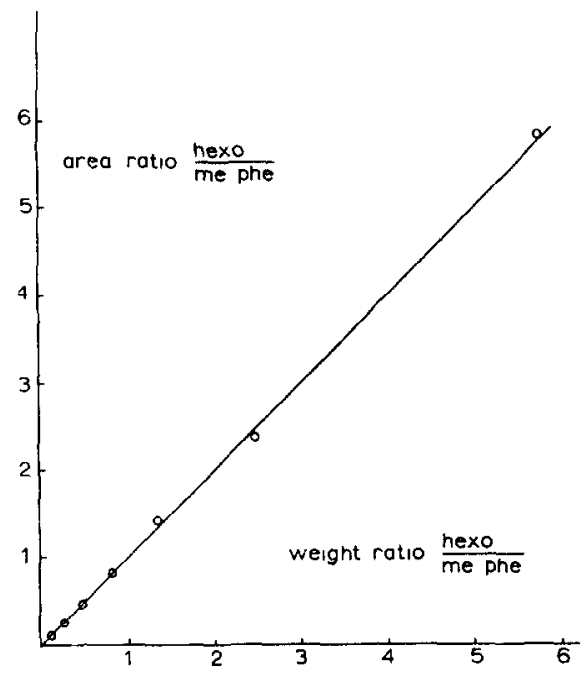

FIG. 1. The relation between area ratio of hexobarbital/methylphenobarbital (measured as height $\times$ width on half height) and weight ratio.

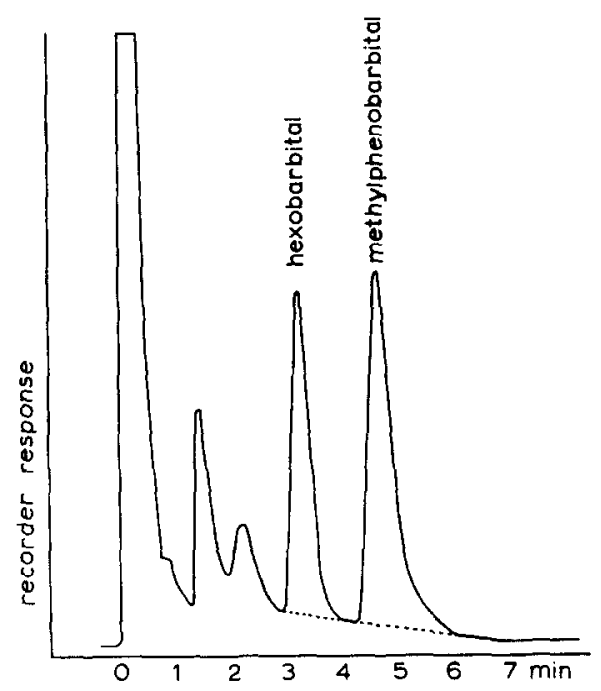

FIG. 2. An example of the gaschromatographic separation between hexobarbital and added methylphenobarbital after extraction of the reaction mixture with chloroform.

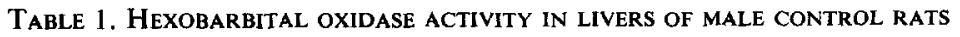

\begin{tabular}{ccccc}
\hline $\begin{array}{c}\text { Liver } \\
\text { supernatant }\end{array}$ & $\begin{array}{c}\% \text { Hexo } \\
\text { metabolized }\end{array}$ & $\begin{array}{c}\text { No. of } \\
\text { animals }\end{array}$ & $\begin{array}{c}\text { Standard value } \\
\text { hexo in } \mu \mathrm{g}\end{array}$ & $\begin{array}{c}\text { No. of } \\
\text { determinations }\end{array}$ \\
\hline $1 \mathrm{ml}$ & $\begin{array}{c}15 \cdot 2 \pm 3 \cdot 4^{*} \\
3 \mathrm{ml}\end{array}$ & 19 & $621 \pm 29$ & 10 \\
\hline
\end{tabular}

* Standard deviation. 
TABle 2. HeXobarbital OXIDASE aCtIVITY IN Livers OF MALE RATS AFTER ONE ORAL DOSE OF ORGANOCHLORINE PESTICIDES

\begin{tabular}{lccc}
\hline Pesticide & $\begin{array}{c}\text { Dose in mg/kg } \\
\text { (half LD }\end{array}$ & \multicolumn{1}{c}{$\begin{array}{c}\text { 1 ml liver } \\
\text { supernatant }\end{array}$} & $\begin{array}{c}3 \text { ml liver } \\
\text { supernatant }\end{array}$ \\
\hline DDT & 150 & $22^{*}(2)$ & $76(3)$ \\
dieldrin & 30 & $40(2)$ & $61(2)$ \\
lindane & 75 & $46(2)$ & $82(2)$ \\
dicofol & 500 & $26(2)$ & $97(2)$ \\
tetradifon & 200 & $44(4)$ & $70(4)$ \\
chlorfenson & 1000 & $57(4)$ & $100(2)$ \\
dichlobenil & 2000 & $35(4)$ & $45(3)$ \\
Control & - & $15 \cdot 2(19)$ & $41(13)$ \\
\hline
\end{tabular}

\footnotetext{
* Expressed as percentages of the standard value of hexobarbital.

+ Number of animals; for measurements with 1 or $3 \mathrm{ml}$ supernatant different animals were used.
}

For dicofol, tetradifon, chlorfenson and dichlobenil stimulation of hexobarbital oxidase has not been described hitherto. The stimulation found varies for the different pesticides. Perhaps it also varies with the dose level, but by giving a half $\mathrm{LD}_{50}$ we have tried to correct for the percentage uptake of the substance and to use a "physiological active" dose. Although a comparison of the stimulating potency is very difficult, it is probable that dichlobenil has the weakest potency.

From these results it was concluded that this method can be useful for measurement of the induction of hexobarbital oxidase in toxicological studies. The method has the advantage that by using a gaschromatographic determination of hexobarbital, an internal standard could be used so that only one extraction is necessary. When a gaschromatograph is present in the laboratory a simple and accurate determination of hexobarbital oxidase and possibly of other "drug metabolizing" enzymes can be carried out.

Laboratory for Toxicology, National Institute of Public Health, ENGELina M. DEn TONKELAar Utrecht, Aaltjen Klap-van Dujk

The Netherlands SJOERD L. WIT

\section{REFERENCES}

1. D. Gilbert and L. Golberg, Fd. Cosmet. Toxicol. 3, 417 (1965).

2. A. Ghazal, W. Koransky, J. Portig, H. W. Vohland and J. Klempak, Archs exp. Path. Pharmak. 249, 1 (1964).

3. L. G. HART and J. R. Fouts, Proc. Soc. exp. Biol. 114, 338 (1963).

4. J. R. COOPER and B. B. BRodie, J. Pharmac. exp. Ther. 114, 409 (1955).

5. N. C. JAIN and P. KIRK, Microchem. J. 12, 249 (1967).

6. J. F. ReITH, R. F. VAN DER HeIDe and R. F. A. ZwAal, Pharm. Weekbl. 100, 219 (1965).

7. M. W. ANDERS, Analyt. Chem. 38, 1945 (1966).

Biochemical Pharmacology, Vol. 18, pp. 265-268. Pergamon Press. 1969. Printed in Great Britan

\section{Effect of phenoxybenzamine on the turnover rate of heart norepinephrine}

(Received 2 April 1968; accepted 14 June 1968)

Changes in the turnover rate of norepinephrine (NE) are a much better index of sympathetic tone than are changes in the tissue concentration of the amine, which might remain constant or even decline despite an increased rate of synthesis. Recent reviews from this laboratory have emphasized 